\title{
Extraction and Characterization of Bioactive Compounds from Cultured and Natural Sponge, Haliclona molitba and Stylotella aurantium Origin of Indonesia
}

\author{
Rory Anthony Hutagalung, Victor, Myra Karjadidjaja, Vivitri Dewi Prasasty, and Noryawati Mulyono
}

\begin{abstract}
Soft-body invertebrates, such as sponges are physically-weak organisms; however they mostly survive for thousands of years. This is due to the fact that they are capable of defending themselves from predators by releasing toxic substances as their secondary metabolites against the predators. These compounds are highly potent for medicine such as anti-microbial, anti-cancer, and anti-inflammatory activities. A large quantity of sponges are needed to produce bioactive compounds as their secondary metabolites only could get in small amount. This could provoke the sea-sponges overexploitation. Cultured sponges could be the one of the alternatives to prevent excessive natural sea-sponge exploitation. However, it is still unclear whether the cultured sponge has similar bioactivity compare to the natural sponge as well. The purposes of this research were to extract secondary metabolites from natural and cultured sea-sponges (Haliclona molitba and Stylotella aurantium), and to evaluate their antimicrobial, hemolysis, and hemagglutination activities with differentiation (?) on cultured and natural sponges. Aquadest and methanol were used as solvents on this research. Methods were used to determine the antimicrobial activity using the round disc diffusion. Hemolysis and hemagglutination assays utilized red blood from Deutsch Democratic Yokohama (DDY) mice. Hemagglutination and hemolysis results were measured with a microplate reader. The extraction yield of natural sponge was not significantly different from cultured one. The aqueous extract resulted in higher yield than methanolic extract. As antimicrobial activity, Bacillus cereus was the most sensitive against the crude extracts either from the natural and cultured sponges among all tested bacteria. Although both types of sponges did not show hemolysis activity, they showed hemogglutination activity.
\end{abstract}

Index Terms-Antimicrobial, cultured sponge, Haliclona molitba, hemagglutination, hemolysys, and Stylotella aurantium.

\section{INTRODUCTION}

As the biggest archipelago country, Indonesia exhibits high marine biodiversity, particularly the coral reef ecosystem. Due to high competition in the ecosystem, physically weak organisms need to develop a biological defense system in order to be able to protect themselves. Sponges, for example, need to develop a secondary metabolism system which is primarily used for self-defense. The toxic compounds produced from the sponge's secondary

Manuscript received June 21, 2013; revised September 23, 2013. This work was supported by Atma Jaya Catholic University of Indonesia and PT. Dinar Daru Lestari.

The authors are with R. A. Hutagalung is with the Faculty of Biotechnology, Atma Jaya Catholic University of Indonesia, Jend. Sudirman Street No.51, Jakarta 12930 (e-mail: rory.hutagalung@atmajaya.ac.id, vicz_2709@yahoo.co.id,

vivitri.dewi@atmajaya.ac.id,noryawati@atmajaya.ac.id). metabolism are highly potential to be used as medicine.

Nowadays 850 sponge species have been discovered in Indonesia and some of them are found to contain secondary metabolites. These compounds have shown to have anti tumor and anti-inflammatory activities. Some examples of secondary metabolites found in sponges are terpenes, alkaloids, and polyphenols. Specific compounds which have shown promising activities are among others: calyculins from Dicodermia calyx, lantruculins from Lantrunculia magnifica, and spongistatins from Spongia sp., and Spirastrella sp. [1]-[3]. In addition to having bioactive compounds, some marine sponges, such as suberitin (which is derived from Suberites douncula) and heolysin (which is derived from Tetchya lincurum), also showed hemolytic and hemagglutination activities [3]. The fact that sponges are potentially useful as ingredients for medicine could threaten the sustainability of these sponges because a massive amount of sample is needed to obtain secondary metabolites from sea sponges. To produce one gram of anticancer compound, for example, one ton of Ecteinascidia turbinate sponge is needed [4]. Therefore, an alternative source of raw materials should be found.

One possible alternative for acquiring sufficient amount of secondary metabolites is by cultivating sponges. Sponge and other reef organism cultivation has much been developed lately, especially through transplantation method. Coral transplantation method is relatively easy to be carried out and its production can be customized in terms of quantity and time.

The use of cultured sponges as alternative materials, however, requires careful content analysis because natural sponges and cultured sponges could produce different substances. Sponges which belong to the same species may have different secondary metabolites as they live in different places [3]. Natural Mycale hentscheli, for example, has the ability to produce secondary metabolites. Yet, secondary metabolites are not produced by cultured Mycale hentscheli [5]. In addition, the extracted secondary metabolites also depend on the solvent used during the extraction process [6].

This study aims to extract and to characterize the secondary metabolite from sponges originated from Indonesia (Haliclona molitba and Stylotella aurantium) based on antimicrobial, hemolytic, and hemagglutination activities by comparing natural and cultured sponges and types of solvent used.

\section{MATERIALS AND METHOdS}

\section{A. Materials}

Natural and cultured sponges Stylotella aurantium and 
Haliclona molitba were used in this study. The natural sponges were collected from the water around the Thousand Islands, Indonesia, while the cultured ones were collected from Pramuka Island, which part of the Thousand Islands clusters.

\section{B. Bioactive Compounds Extraction}

Bioactive compounds were extracted following Bakus and

TABLE I: YIELD PERCENTAGE AND INHIBITION ZONE OF STYLOTELLA AURANTIUM AND HALICLONA MOLITBA CRUDE EXTRACT

\begin{tabular}{|c|c|c|c|c|c|c|}
\hline \multirow{2}{*}{ Source } & \multirow{2}{*}{ Solvent } & \multirow{2}{*}{ Yield (\%) } & \multicolumn{4}{|c|}{ Inhibition zone (mm) } \\
\hline & & & Bacillus cereus & Escherichia coli & Staphylococcus aureus & Salmonella typhi \\
\hline \multicolumn{7}{|c|}{ Stylotella aurantium } \\
\hline \multirow{2}{*}{ Natural } & Aqueous & $16.05 \pm 2.27$ & $0.3 \pm 0.3$ & $0.0 \pm 0$ & $0.3 \pm 0.3$ & $0.0 \pm 0$ \\
\hline & Methanol & $11.04 \pm 0.24$ & $7.3 \pm 1.2$ & $2.3 \pm 1.5$ & $2.3 \pm 1.5$ & $2.7 \pm 1.2$ \\
\hline \multirow{2}{*}{ Cultured } & Aqueous & $18.06 \pm 2.53$ & $2.0 \pm 1.5$ & $0.0 \pm 0$ & $1.0 \pm 1.0$ & $0.0 \pm 0$ \\
\hline & Methanol & $8.86 \pm 2.01$ & $2.7 \pm 1.8$ & $1.3 \pm 1.3$ & $1.3 \pm 0.9$ & $1.7 \pm 1.7$ \\
\hline \multicolumn{7}{|c|}{ Haliclona molitba } \\
\hline \multirow{2}{*}{ Natural } & Aqueous & $25.59 \pm 10.64$ & $1.0 \pm 0.0$ & $1.0 \pm 1.0$ & $0.0 \pm 0.0$ & $0.0 \pm 0.0$ \\
\hline & Methanol & $22.22 \pm 10.29$ & $0.67 \pm 0.33$ & $0.0 \pm 0.0$ & $0.0 \pm 0.0$ & $0.0 \pm 0.0$ \\
\hline \multirow{2}{*}{ Cultured } & Aqueous & $13.20 \pm 2.16$ & $2.33 \pm 0.88$ & $0.0 \pm 0.0$ & $3.67 \pm 1.86$ & $0.0 \pm 0.0$ \\
\hline & Methanol & $7.70 \pm 1.79$ & $3.67 \pm 0.33$ & $0.0 \pm 0.0$ & $5.0 \pm 2.52$ & $0.0 \pm 0.0$ \\
\hline
\end{tabular}

The amount of methanol used was 20 times as much as the weight of the sponge $(5 \% \mathrm{w} / \mathrm{v})$. The solution was then filtered through Whatman Filter Paper No. 3. Filtered solution was air dried then stored in a refrigerator $\left(4^{\circ} \mathrm{C}\right)$ for further use.

The amount of methanol used was 20 times as much as the weight of the sponge $(5 \% \mathrm{w} / \mathrm{v})$. The solution was then filtered through Whatman Filter Paper No. 3. Filtered solution was air dried then stored in a refrigerator $\left(4^{\circ} \mathrm{C}\right)$ for further use.

When the distilled water was used for extraction, the sponge was boiled for 5 minutes in the boiling water. The solution from this process was then filtered with Whatman Filter Paper No. 3. Filtered solution was evaporated in a vacuum oven $\left(50^{\circ} \mathrm{C}\right)$ until it was dry and then the extract was stored in a refrigerator $\left(4^{\circ} \mathrm{C}\right)$ for further use.

\section{Antimicrobial Activity Assay}

Antimicrobial activity assay was conducted using the disc diffusion method. Petri dishes with nutrient agar were inoculated with four species of bacteria, i.e. Bacillus cereus, Escherichia coli, Salmonella typhi, and Staphylococcus aureus. Those bacterial cultures were obtained from the Microbiology Laboratory at Atma Jaya Catholic University of Indonesia. Sponge extract was dissolved in distilled water to achieve the concentration of $30 \mathrm{mg} / \mathrm{ml}$. Sponge extract solution was sterilized by passing it on GV $0.22 \mu \mathrm{m}$ Millipore Filter. $0.01 \mathrm{ml}$ of the extract solution from each bacteria species was dropped into each paper discs (6 $\mathrm{mm}$ diameter) and placed in the middle of inoculated petri dish. Petri dishes were incubated overnight at the temperature of $37^{\circ} \mathrm{C}$, and then the inhibition zone was measured.

\section{Hemolytic Assay}

Hemolytic assay was conducted using the method used in the study by Sepcic et al. [3] with some modifications. Fresh blood from Deutsch Democratic Yokohama (ddY) mice was used for hemolytic assay. The erythrocyte was prepared by centrifugating the blood at $2000 \mathrm{rpm}$ for 4 minutes at the temperature of $4{ }^{\circ} \mathrm{C}$. Clear and colorless supernatant was discarded, while the pellet, which was the erythrocyte, was washed with physiological saline. The mass of physiological saline needed was 9 times of as much as the amount of pellets obtained. This step was repeated three times. Pellet which
Green method [7] with some modifications. Extraction was conducted by using methanol and distilled water as solvents. When methanol was used for extraction, the sponge was dried via lyophilization for two days, and then the sponge tissue was grounded until it became powder and then soaked in methanol for five hours. had been washed was then diluted with buffer containing $0.13 \mathrm{M} \mathrm{NaCl}$ in $0.02 \mathrm{M} \mathrm{pH} 7.4$ Tris- $\mathrm{HCl}$ until the concentration was $0.5 \% \mathrm{w} / \mathrm{v}$.

Hemolytic activity was assayed with Micro plate Reader (BioRad), Model 680 and U-bottom microplate. Each well was filled with $20 \mu \mathrm{L}$ sponge extract which had been dissolved in buffer to produce erythrocyte suspension with the concentration of $10 \mathrm{mg} / \mathrm{ml}$. Subsequently, $100 \mu \mathrm{l}$ of erythrocyte suspension was added for hemolysis assay. Positive control used was $1 \%$ Triton $\mathrm{X}-100$ and negative control was a buffer and added with erythrocyte suspension. The absorbance value was measured with a microplate reader at the wavelength of $655 \mathrm{~nm}$ on $0 ; 5 ; 10 ; 15 ; 20$ minute time span. During the measurement interval, the microplate was agitated at moderate speed at $25^{\circ} \mathrm{C}$.

\section{E. Antimicrobial Activity Assay}

Hemagglutination assay was conducted following Sepcic et al. method [3] with some modifications. Erythrocyte suspension which was made for hemolytic assay was added to U-bottom microplate. $100 \mu \mathrm{l}$ of erythrocyte suspension was added for each well. $20 \mu \mathrm{l}$ of sponge extract which had the concentration of $30 \mathrm{mg} / \mu \mathrm{l}$ was then added to each well. Hemagglutination activity could be observed visually after 45 minute incubation at the temperatue of $25^{\circ} \mathrm{C}$. Before the microplate could be seen visually, it was agitated at a medium speed for 1 minute.

\section{RESUlts}

The yield percentages of cultured sponge and natural sponge were not significantly different ( $p=0.961$ ); however, the yield percentages were influenced by the type of solvents used. The yield percentages of both $\mathrm{S}$. aurantium and $\mathrm{H}$. molitba extracts in methanol showed significantly higher activities $(p=0.007)$ rather than in water (Table I).

In antimicrobial assay, all extracts were able to inhibit $B$. cereus growth and the greatest inhibitory activity $(7.3 \pm 1.2)$ was shown by the extract of $S$. aurantium using methanol as solvent. In fact, $S$. aurantium extracts showed inhibitory activity on all bacteria tested. However, extracts with 
aqueous solvent generally showed weaker inhibitory activity. Extracts from the sponge $H$. molitba could only inhibit $B$. cereus and $S$. aureus.

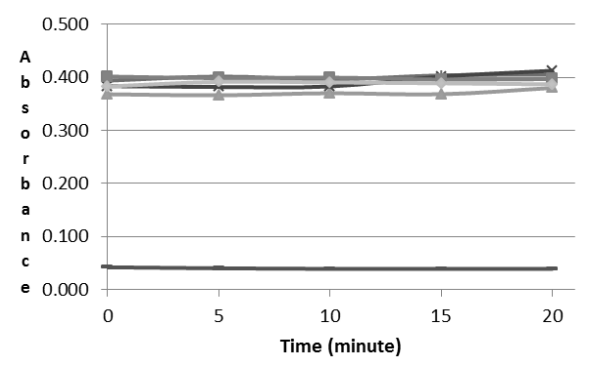

Haliclona molitba

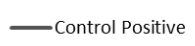

$\rightarrow$ Control Negative

- Natural, Aqueous

* Natural, Metanol

$\rightarrow-$ Cultured, Aqueous

$\rightarrow$ Cultured, Metanol

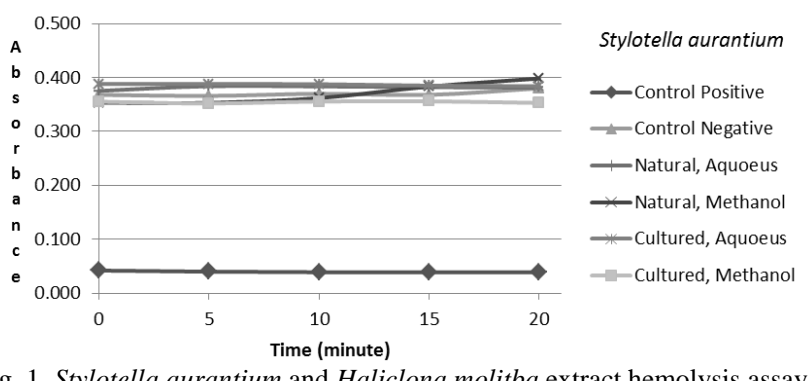

Fig. 1. Stylotella aurantium and Haliclona molitba extract hemolysis assay result based on absorbance value on $655 \mathrm{~nm}$ wavelength.

For hemolysis assay, all extracts from both $S$. aurantium and H. molitba, either natural or cultured, either using aqueous solvent or methanol solvent showed no hemolytic activity (Fig. 1). All samples did not show any absorbance reduction while the absorbance value of positive control was far below the absorbance value of all samples.

TABLE II: HEMAGGLUTINATION ASSAY RESULT (+ : Positive HeMagGlutination, - : NEGATIVE HeMAGGLUTINATION)

\begin{tabular}{|c|c|c|}
\hline Source & Solvent & Hemagglutination \\
\hline \multicolumn{3}{|c|}{ Stylotella aurantium } \\
\hline \multirow[t]{6}{*}{ Natural } & Aquadest & + \\
\hline & & + \\
\hline & & + \\
\hline & Methanol & + \\
\hline & & - \\
\hline & & - \\
\hline \multirow[t]{6}{*}{ Cultured } & Aquadest & + \\
\hline & & + \\
\hline & & + \\
\hline & Methanol & - \\
\hline & & + \\
\hline & & - \\
\hline \multicolumn{3}{|c|}{ Haliclona molitba } \\
\hline \multirow[t]{6}{*}{ Natural } & Aquadest & + \\
\hline & & + \\
\hline & & + \\
\hline & Methanol & - \\
\hline & & + \\
\hline & & - \\
\hline \multirow[t]{6}{*}{ Cultured } & Aquadest & + \\
\hline & & + \\
\hline & & - \\
\hline & Methanol & + \\
\hline & & + \\
\hline & & - \\
\hline
\end{tabular}

In terms of hemagglutination assay, 8 out of 12 samples of $S$. aurantium and 8 out of 12 samples of $H$. molitba showed hemagglutination activity (Fig. 2). Hemagglutination activity was shown by the formation of red sediment on the bottom of the microplate well. The extracts from aqueous solvent showed more hemagglutination activity than the one from methanol solvent (Table II). In terms of the type of sponge, the natural and cultured sponge did not show any difference in the hemmaglutination activity. As for S. aurantium, all extracts showed hemagglutination activity when aqueous solvent was used, while only two out of 6 samples of those extracts indicated these activities when methanol solvent was used. As for H. molitba, 5 out of 6 samples using aqueous solvent showed hemagglutination activity and 3 out of 6 samples with methanol solvent showed hemagglutination activity.

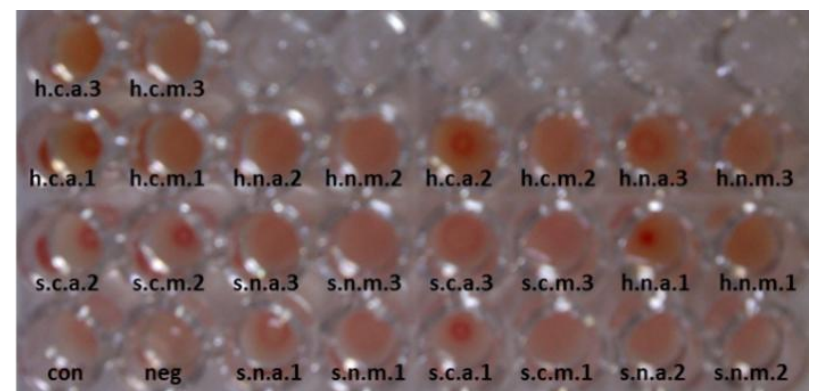

Fig. 2. Hemagglutination assay on 96 well U-bottom microplate. (con: control, neg: control negative, s: S. aurantium, h: H. molitba, n: natural, c: cultured, a: aqueous, m: methanol, \#: number of replicates).

\section{DISCUSSION}

As mentioned in previous section, neither the natural sponge nor the cultured sponge influenced the yield percentage in the research. It was the type of solvent that determines the yield percentage; aqueous solvent produced higher yield percentage than the methanol solvent. Similar results were found in Kumar et al. [8] on Spongosorites halichondriodes sponge. In contrast, Boobathy et al. [6] showed that Callyspongia diffusa with methanol solvent performed greater yield percentage. One possible cause to such differences was the type of sponge used. Different solvent also have different polarity. The polarity of the bioactive compound and that of the solvent determine the extractive yield. The polarity of water is higher than that of methanol and thus, the yield percentage of water was also higher. The higher polarity of water might result more yield than methanol which has lower polarity. The average yield percentage found in this study $(15.34 \%)$ was greater than that of the studies conducted by Boobathy et al. [6] (6.05\%) and Kumar et al. [8] (12.5\%).

In regard to the bacteria inhibitory activity assay, crude extracts from sponge samples were most effective in inhibiting the growth of $B$. cereus and $S$. aureus, but less effective in inhibiting the growth of $E$. coli and $S$. typhi. Unlike the two other bacteria, B. cereus and $S$. aureus belonged to gram positive grove that had a thick peptidoglycan layer, which were superficial to the cell membrane. Inhibition against the two bacteria might have been related to the structure of this cell membrane. In terms of the solvent, the crude extract using methanol solvent had a higher inhibitory activity than the crude extract from aqueous 
solvent. This suggested that bioactive compounds which inhibit the growth of bacteria were mostly semi-polar, and thus, could be easily extracted by methanol which was also semi polar. Antimicrobial compounds produced by sponge might play an effective role in improving the efficiency of getting food which was in the form of bacteria [9].

Both types of sponge extracts did not show any hemolysis activity. This indicates that no cytotoxic activity could be a candidate of whether antineoplastic or anticancer compounds [10].

Another activity tested using these extracts was hemagglutination activity. Both types of samples were proven to have hemagglutination activity. Better hemagglutination activity was observed in extracts using aqueous solvent. Hemagglutination activity is generated by protein and the protein found in sponges which usually shows hemmaglutination activity is lectin. It should however be pointed out that the size of such a protein varies and that some types of lectin may not trigger hemagglutination activity. Lectin protein with size of $60 \mathrm{kDa}$ also showed antimicrobial activity against pathogenic bacteria and fungi [11]. Several types of lectin show the activity which binds tumor cells [12]. Therefore, the finding of hemagglutination activity resulted in the possibility of the presence of lectin, which potentially had antimicrobial activity or antitumor activity.

In general, our study indicated that cultured sponges and natural sponges did not show any difference in both the yield percentage and activity assays. The opposite result was found in Pelorusida A. The compound was produced by the natural sponge Mycale hentscheli, but not by the cultured one [5]. However, Duckworth and Battershill [13] reported that the production of chemical compounds in cultured sponge may be equal to or even greater than its natural condition. After all, the production of bioactive compounds in sponge is determined by their environmental factors, namely the presence of predators, season, temperature, sea depth, microbial infection, type of food, and the appearance of wounds on the body of the sponge [14].

The fact that the yield percentage result, inhibition assay, hemolysis, and hemagglutination assay from natural and cultured sponges were similar in this experiments might have been related to the environmental conditions. Indeed, the cultured site (Pramuka Island) is close as it is one of the islands of Thousand Island cluster from where the natural sponge originated. One advantage of this findings is that the cultured sponges $H$. molitba and $S$. aurantium can be used as an alternative feedstock to substitute for the wild one. Therefore, excessive exploitation of natural sponge can be avoided. Another advantage of the cultured sponge is related to stock management. Stock procurement of cultured sponge is fully customizable to the needs, both in terms of quantity and time.

\section{CONCLUSION}

The yield percentage of native Indonesian sponge was relatively high (on average $15.34 \%$ ) and the yield percentage using aqueous solvent was greater than that using methanol solvent. Bioactive compounds extracted from sponges were capable of inhibiting B. cereus and $S$. aureus growth. The sponges extracts did not show any hemolytic activity but all of them, especially those using aqueous solvent, exhibited haemagglutination activity. There were no any differences between natural and cultured sponges in terms of extract yield percentage, bacteria inhibition, dan hemagglutination activities. The cultured sponges could then be used as alternative raw material to replace the natural ones.

\section{ACKNOWLEDGMENT}

We express our gratitute to Atma Jaya Catholic University of Indonesia for funding this research as well as providing facilities to conduct this research. We are also thankful to PT. Dinar Darum Lestari for supplying samples needed in this research.

\section{REFERENCES}

[1] G. J. Bakus and G. Green, "Toxicity in sponges and holothurians: a geographic pattern,” Science, vol. 185, pp. 951-953, 1981.

[2] P. R. Begquist and J. J. Bedford, "The incidence of antibacterial activity in marine demospongie, systemic and geographic consideration," Mar Biol,. Vol. 46, pp. 215-221, 1978.

[3] S. Boobathy, T. T. A. Kumar, and K. Kathiresan, "Isolation of symbiotic bacteria and bioactive proteins from the marine sponge," Callyspongia diffusa. Indian J Biotechnol., vol. 8, pp. 272-275, 2009.

[4] S. Boobathy, P. Soundarapandian, V. Subasri, N. Vembu, V. Gunasundari, "Bioactivites of protein isolated from marine sponge," Sigmadocia fibulatus. Curr Res J Biol Sci., vol. 1, pp. 160-162, 2009.

[5] A. Duckworth and C. Battershill, "Sponge aquaculture for the production of biologically active metabolites: the influence of farming protocols and environment," Aquac., vol. 221, pp. 331-329, 2003.

[6] S. M. A. Kawsar, S. M. A. Mamu, M. S. Rahman, H. Yasumitsu, and Y. Ozeki, "In vitro antibacterial and antifungal effects of a $30 \mathrm{kDa}$ D-galactoside-specific lectin from the demosponge," Halichondria okadai. Int J Biol Life Sci., vol. 6, pp. 31-37, 2010.

[7] M. Koopmans, D. Martens, and R. H. Wijttels, "Towards commercial production of sponge medicines," Mar Drugs, vol. 7, pp. 787-802, 2009.

[8] M. S. Kumar, S. Gupta, and A. K. Pal, "Isolation of bioactive proteins from the marine sponges Spongosorites halichondriodes (Dendy. 1905)," World Appl Sci J., vol. 17, pp. 729-734, 2012.

[9] S. K. Lam and T. B. Ng, "Lectins: production and practical applications," Appl Microbiol Biotechnol., vol. 89, pp. 45-55, 2011.

[10] M. J. Page, P. T. Northcote, V. L. Webb, S. Mackey, and S. J. Handley, "Aquaculture trials for the production of biologically active metabolites in the New Zealand sponge Mycale hentscheli (Demospongiae: Poecilosclerida)," Aquac, vol. 250, pp. 256-269, 2005.

[11] P. Prahalathan, S. Bragadeeswaran, R. Sasikala, U. Kangarajan, and P. Kumaravel, "Antimicrobial and hemolytic activities of marine sponge Halichondria panacea," J Herbal Med Toxicol., vol. 3, pp. 45-48, 2009.

[12] K. L. Rinehart, "Secondary metabolites from marine organisms," Ciba Foundation Symposium, vol. 171, pp. 236-264, 1992.

[13] K. Sepcic, S. Kauferstein, D. Mebs, and T. Turk, " activities of aqueous and organic extracts from tropical marine sponges," Mar Drugs, vol. 8, pp. 1550-1566, 2010.

[14] N. L Thakur and W. E. G. Muller, "Biotechnological potential of marine sponges," Current Science, vol. 86, pp. 1506-12, 2004.

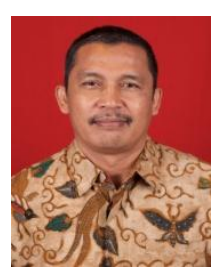

Rory Anthony Hutagalung was born in P. Siantar, Indonesia in 1960. He earned his bachelor degree in fishery science from Bogor Agricultural University, Bogor - Indonesia in 1984. He obtained his master degree in aquatic environment from Université Paul Sabatier, Toulouse, France in 1995, and his Doctorate Degree in Environmental Science from Ecole Nationale Supérieure Agronomique de Toulouse,

France in 1998

Rory Anthony is a full time lecturer at Faculty of Biotechnology, Atma Jaya Catholic University of Indonesia in Jakarta and French teacher at Institut Français Indonesia, Jakarta. He is also a country representative of 
Pacific Hermit Crabs, France. He also contribute his knowledge for some universities (Universitas Pakuan, Universitas Terbuka, and Bogor Agricultural University). Some of his publications are Population Dynamic of Dendrophthya sp.-Associated Bacteria in Natural and Artificial Habitats (Susan Soka, Rory Anthony Hutagalung, Yogiara et al. 2011), 57-60. In HAYATI Journal of Biosciences 18 (2), Aclimatization of Marine Ornamental Fishes Through Chemical Approach. Hutagalung RA, Vivitri SD, Yanti, Richard, K, Steandy, Windi and Fredy. (2011). Proceeding ICFAS (International Conference on Fishery and Aquatics Sciences). Paris 24-27 June 2011, and Antibacterial Activity of Marine Bacteria Associated with sponge Aaptos sp. against Multi Drugs Resistant (MDR) strains.
Radjasa, OK, Kencana DS, Sabdono A, Hutagalung, RA, and Lestari, ES (2007). Jurnal Matematika dan Sains 12 (4): 146-152. His main research interest are marine ecology and fishery science.

Dr. Ir. Rory Anthony Hutagalung is the secretary of Indonesian Society of Scientist Aquaculture and the winner of "Prix Paul Escande" trophy as one of the 1998 best dissertations of "INP Toulouse, France" society and the winner of "Prix MAHAR SHUTZENBERGER 1998" trophy for the best research (among the Indonesian students of doctorate degree in France). 